\title{
An Initiative the Used of Sterile Insect Technique (SIT) To Control Filariasis in Indonesia
}

\section{Inisiatif Penggunaan Teknik Serangga Mandul (TSM) Untuk Pengendalian Filariasis di Indonesia}

\author{
Beni Ernawan dan Hadian Iman Sasmita \\ Center for Isotopes and Radiation Application, BATAN \\ Jl. Lebak Bulus Raya No. 49 Jakarta 12440, Indonesia \\ Email : beni_e@batan.go.id
}

\begin{abstract}
Filariasis as part of the neglected tropical disease is one of the health problems in the world. Filariasis divided into onchocerciasis (river blindness) and lymphatic filariasis or elephantiasis. This disease caused by filarial nematode parasites Onchocerca volvulus, Wuchereria bancrofti, Brugia malayi and Brugia timori. Filariasis transmitted by several mosquito genera as the vector. Indonesia as endemic filariasis, agreed on plays a role on World Health Organization (WHO) global filariasis elimination in 2020. Sterile insect technique (SIT) is a potential method which can be applied to filariasis elimination program by controlling the mosquito population. Basic principles of SIT involve mass rearing of species target, sterilization process using gamma-rays and releasing sterile male insect into a target area. SIT combined with other methods under one management as Area-wide Integrated Pest Management (AWIPM) to increasing effectiveness and successful filariasis elimination program in Indonesia. Filariasis elimination program in Indonesia has several challenges and needed public participation to achieve program goals.
\end{abstract}

Key words : filariasis, Indonesia, sterile insect technique (SIT)

\begin{abstract}
ABSTRAK
Filariasis sebagai bagian dari penyakit tropis yang terbengkalai merupakan salah satu masalah kesehatan di dunia. Filariasis dibagi menjadi onchocerciasis dan filariasis limfatik atau kaki gajah. Penyakit ini disebabkan oleh parasit nematoda filarial Onchocerca volvulus, Wuchereria bancrofti, Brugia malayi dan Brugia timori. Filariasis ditularkan oleh beberapa genera nyamuk sebagai vektor. Indonesia sebagai endemik filariasis, sepakat memainkan peran dalam eliminasi filariasis global yang diagendakan oleh world health organization (WHO) pada tahun 2020. Teknik serangga mandul (TSM) adalah metode potensial yang dapat diterapkan pada program eliminasi filariasis dengan mengendalikan populasi nyamuk. Prinsip dasar SIT melibatkan pembiakan populasi target secara massal, proses sterilisasi menggunakan sinar gamma dan melepaskan serangga jantan steril ke daerah sasaran. TSM dapat dikombinasikan dengan metode lain di bawah satu manajemen terpadu, yaitu area-wide integrated pest management (AW-IPM) untuk meningkatkan efektivitas dan keberhasilan program eliminasi filariasis di Indonesia. Program eliminasi filariasis di Indonesia memiliki beberapa tantangan dan kebutuhan partisipasi masyarakat untuk mencapai tujuan program.
\end{abstract}

Kata kunci : filariasis, Indonesia, teknik serangga mandul (TSM)

\section{INTRODUCTION}

Filariasis is one of the health problems in the world, it can be categorized and included as part of a large group of neglected tropical diseases (http://www.who.int/neglected_diseases/diseases/e n/). Commonly, filariasis can be divided into onchocerciasis (river blindness) and lymphatic filariasis or elephantiasis (huge elephant-shapedlegs and large scrotum) [1,2]. Lymphatic filariasis caused by filarial nematode parasites Wuchereria bancrofti, Brugia malayi and Brugia timori, while onchocerciasis caused by Onchocerca volvulus [3]. Filariasis clinical cases found in tropical countries such as sub-Saharan Africa, Asia, Latin America and Pacific Islands [4]. More than 90\% 
estimation of filariasis infection caused by Wuchereria bancrofti, occurs in sub-Saharan Africa, the Indian subcontinent, Southeast Asia, Pacific Islands and Latin America. Brugia malayi mainly occurs in China, Malaysia, India Philippines, Indonesia and some Pacific Islands. While Brugia timori is endemic in Timor Island, Indonesia [5]. More than 70\% filariasis cases in Indonesia caused by Brugia malayi (http://www.depkes.go.id/article/view/150730000 01/prevalansi-penyakit-kaki-gajah-filariasisberhasil-diturunkan.html). Filariasis cases in many endemic countries were well documented. The following are some examples of filariasis clinical cases in some countries. MWAKITALU et al. [6] reported lymphatic filariasis infection, disease and transmission in Tanga, Tanzania. AGUIARSANTOS et al. [7] reported lymphatic filariasis and intestinal parasitic infection of school-aged children in Pernambuco, Brazil. In India, microfilariae Wuchereria bancrofti attacked breast woman [8,9]. RUIZ et al. [10] reported elephantiasis clinical cases in Sao Tome and Principe, Africa.

Indonesia agreed to play an active role in filariasis program, in accordance with the World Health Organization (WHO) in global agreement filariasis elimination in 2020. The efforts of filariasis elimination can be done systematically using integrated potential strategies. Potential strategies involved vector control and mass drug administration to interrupt or cut the chain of filariasis transmission in the endemic area and also prevent disabilities due to filariasis [11-13]. Filariasis transmission closely related to the role of mosquito species as the vector. In Indonesia, there are more than 23 species of vector mosquitoborne filariasis consisting of the genera Anopheles, Aedes, Culex, Mansonia, and Armigeres [14]. If the population of mosquitoborne filariasis in the endemic area can be reduced, it is expected that filariasis clinical cases will also decrease. Filariasis vector control necessary to develop using potential methods.

Nuclear research and development not only focused on energy (nuclear power plant), but also in other scopes, i.e. human health, food and agriculture, environment and water resources (http://www-naweb.iaea.org/na/). Gamma rays which are emitted from radioisotopes, can be applied to insect pest population control, in this case is filariasis vector as known as sterile insect technique (SIT). The SIT is the "birth control". In this technique, wild female mosquitoes of the population are not able to produce progeny when they are inseminated with sterile male (http://www-naweb.iaea.org/nafa/ipc/sterile-

insect-technique.html). The purpose of this paper is to review the use of nuclear energy in term of SIT to control filariasis vector population in Indonesia.

\section{FILARIASIS IN INDONESIA}

\section{The parasites, epidemiology and vector}

Indonesia is an archipelago country in Southeast Asia, lying between the Indian and the Pacific Oceans. Astronomically, Indonesia layout is between $6^{\circ}$ North Latitude- $11^{\circ}$ South latitude and $95^{\circ}-141^{\circ}$ East Longitude. It means that Indonesia has tropical climates and received the sunlight throughout the year. Indonesia has high water availability and humidity, an ideal condition for the growth and development of a variety of animal and plant species. Indonesia is an endemic filariasis, mainly caused nematode parasites Brugia malayi, Brugia timori and Wuchereria bancrofti [5,15-18]. Brugia malayi classified into two major forms as zoophilic and anthropophilic [2,19]. Anthropophilic Brugia malayi strain confirmed the nocturnal periodicity and also exclusively infects humans, in accordance with the biting habits of the main vector (Anopheles mosquito). Zoophilic Brugia malayi strain mainly confirmed the nocturnal sub-periodicity. This strain transmitted Mansonia mosquito. Brugia timori is an endemic filarial nematode parasite and only found in Indonesia (East Nusa Tenggara Province) and Timor Leste. Biologically, Brugia timori similar to Brugia malayi on periodicity: nocturnal periodicity. Brugia timori mostly transmitted Anopheles barbiostris and Anopheles subpictus [2,15]. Wuchereria bancrofti, an anthropophilic filarial parasite, classified into three subtypes based on the periodicity of microfilaria in peripheral blood of infectedhuman, i.e. nocturnal periodic, nocturnal subperiodic and diurnal sub-periodic [2,20]. Nocturnal periodic means that the microfilaria presents into the peripheral blood at night. While, the nocturnal sub-periodicity, the microfilaria presents into the peripheral blood reach the highest peak in the middle of the night. The diurnal periodicity of microfilaria, transmitted by the day-biting mosquito [21]. 
In 2014, there were 14.932 filariasis clinical cases in Indonesia. Figure 1 illustrated the increase of filariasis clinical cases since 2010 until 2014. Provinces with the highest filariasis clinical cases in 2014 were East Nusa Tenggara (3.175), Nanggroe Aceh Darussalam (2.375) and West Papua (1.765). Until 2014, based on finger blood survey in 235 districts/cities have been mapped as an endemic area of filariasis (Ministry of HealthRepublic of Indonesia, 2015). species and its spreads throughout Indonesia causes epidemiology of vector-borne diseases become more complicated. Filariasis transmission dynamics in a region different from other regions because of differences in bio-geography, environment, species/strain vectors, bio-ecology, distribution and socio-cultural patterns and behavior. Data of filarial nematode parasites, vector and the endemic area in some provinces in Indonesia presented in Table 1. Mosquito genera

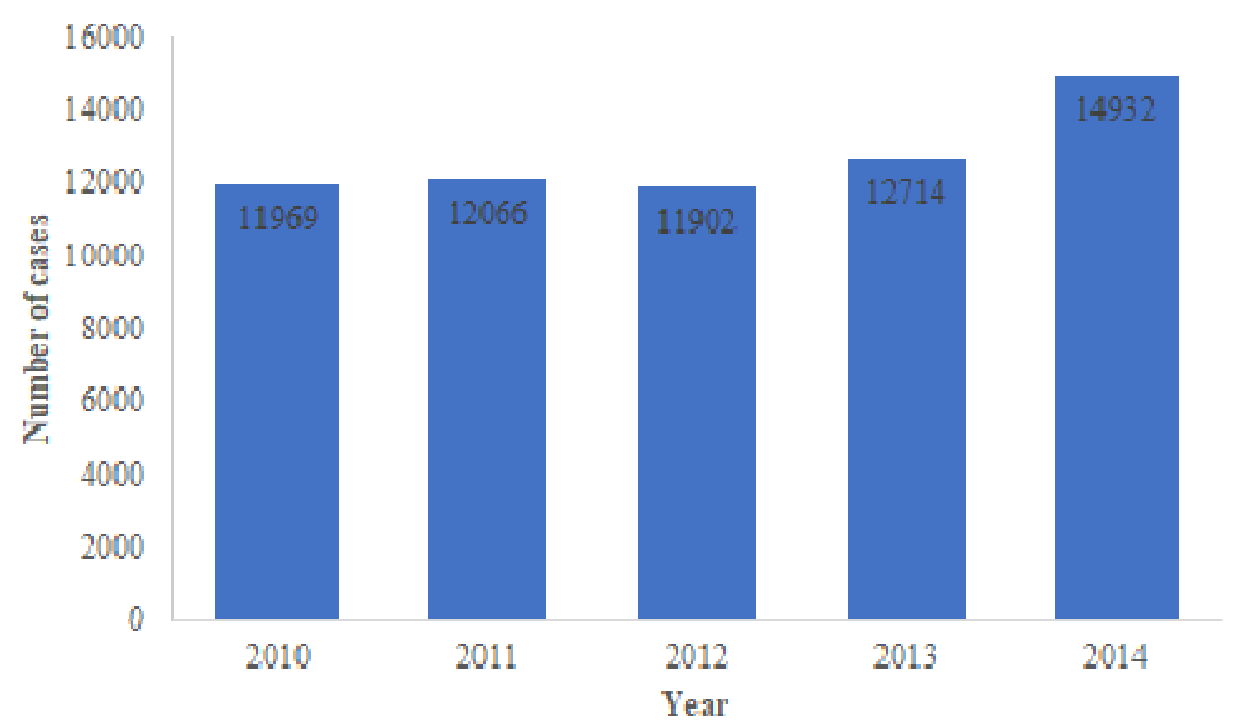

Figure 1. The number of filariasis clinical cases in Indonesia 2010-2014 (Ministry of Health-Republic of Indonesia, 2015)

(Source : http://www.depkes.go.id/resources/download/pusdatin/profilkesehatan-indonesia/profil-kesehatan-indonesia-2014.pdf)

Vector defined as an arthropod that can transmit, transfer and/or be a source of disease transmission to humans. The diversity of vector that have been successfully documented on filariasis transmission in Indonesia were Mansonia, Anopheles and Culex. Brugia malayi

Table 1. Filarial nematode parasites, vector and endemic area in Indonesia

\begin{tabular}{llll}
\hline \multicolumn{1}{c}{ Filarial parasites } & \multicolumn{1}{c}{ Endemic area } & \multicolumn{1}{c}{ Vector } & \multicolumn{1}{c}{ References } \\
\hline Brugia malayi & Nanggroe Aceh Darussalam, & Mansonia bonneae & [18,22-27] \\
& Bengkulu, Riau and North & Mansonia dives & \\
& Sumatera (Sumatera); South & Mansonia uniformis \\
& Kalimantan (Borneo); Central & Anopheles nigerrimus & \\
& Sulawesi, Southeast Sulawesi and & Anopheles peditaeniatus & \\
& South Sulawesi (Celebes) & & \\
Brugia timori & Flores, Alor island (East Nusa & Anopheles barbirostris & {$[15,28-30]$} \\
& Tenggara) & Anopheles subpictus & \\
Wuchereria bancrofti & Flores, Alor island (East Nusa & Anopheles subpictus & {$[15,29,31-36]$} \\
& Tenggara); Jakarta Capital Region, & Anopheles vagus & \\
& West Java (Java); West Papua & Culex quinquefasciatus & \\
& (Papua). & Mansonia uniformis & \\
\hline
\end{tabular}


has documented, mainly found in Sumatera, Kalimantan and Sulawesi. Wuchereria bancrofti spreads in the southern to the east of Indonesia, i.e. Java, East Nusa Tenggara and Papua. Meanwhile, Brugia timori is an endemic filarial parasite in East Nusa Tenggara. Based on Table 1, we can conclude that the entire territory of Indonesia is endemic to filarial parasites. In the other word, the entire territory of Indonesia potentially infected with filariasis.

\section{STERILE INSECT TECHNIQUE AS A PROSPECTIVE METHOD}

\section{Sterile insect technique (SIT)}

Sterile insect technique (SIT) is a biological control method, in which sterile male insect in a large number will be released into the target area. The sterile male will mate with the normal female, then from that mating expected no offspring will be produced. Then, the population of targeted insect will be decreased [37,38]. SIT applied as one of the components of Area-Wide Integrated Pest Management (AW-IPM) [39,40]. Basic principles of SIT:

(a). Mass rearing of target insect at laboratory.

There are several requirements on insect mass rearing. Target insect should be easy on handling and maintenance at the laboratory, viewed from economics and safety perspectives. Insect mass rearing should be conducted with reasonable cost. Management and method must be available to maintain the quality of the target insect, depends on species of target insect [37]. Facility design of laboratory, strain management, employee cost and availability, storage and waste disposal are major substances of mass rearing for the SIT [41]. Sex separation plays crucial roles in mass rearing for the SIT, it means that the sex separation method of the target insect is available. Most of the insect can be separated between female and male based on visual morphology [39]. Male insects are the target of the SIT application, mostly, they are only playing a role in the breeding of their population, not as a disease vector on human (example: mosquitoes) and agriculture commodities (example: fruit flies).

(b). Sterilization process of male insect using ionization energy
The potential of ionization energy (irradiation) of organisms, in this case is insects, will damage the chromosomes of the gonad cells. The chromosomes fragmentations involve dominant lethal mutation, translocation and other chromosomal aberrations that make insect reproduction become sterile [42]. When sperms from sterile male fertilize the egg, the zygote could not develop normally due to the presence of damaged DNA from the sperm causing the death of the embryo. Commonly, the radiation source that used on sterilization process on the SIT is radioisotopes (gamma-rays), electron beam and $\mathrm{X}$ rays. Currently, the radioisotopes Co-60 and Cs137 have been used as the gamma-rays source because these isotopes have long half-live and the energy is relatively high (Table 2) [43].

The absorbed dose on sterilizing irradiation is very important on the SIT. Radiation sensitivity varies among species and depends on many parameters. Environmental, physical and biological factor, i.e. ambient atmosphere, doserate irradiation, temperature, cell stage and characteristics, developmental stage and age, sex, size and weight, diapauses, nutritional state have significant influences in sterilization process and need to be optimized [43-46].

(c). Release of sterile male insect into target area

The release process of the sterile male insect into target area can be conducted in three ways: static release, mobile ground based-vehicles (ground release) and aerial release. Static release use containers where sterile insect on pupae or adult stage is placed. Then, emerged insect will disperse into the target area. This method is very simple, pupae are easily handled and reducing facilities cost. In-ground based-vehicles (ground release), sterile insect on adult stage is dispersed from slow-moving or stopped vehicles. In larger target area, ground based-vehicles (ground release) more quickly than static release. Aerial release method used aircraft to release chilled adult insect, or eject bags/box containing sterile insect. This method can cover the larger area quickly in all terrain condition [47].

\section{(d). Monitoring and evaluation.}

The success of SIT greatly depends on the quality of sterile male insect that released into the target area. Good quality sterile male insect should be maintained from mass rearing stage until shipping and release of the sterile male insect into 
the target area. Parameters of quality control on the SIT consisted of: egg hatch, larval development time, pupal size, percentage adult emergence, sex ratio and timing of emergence, flight ability, pheromone production and response, vision, longevity, startle activity, mating propensity, mating compatibility, mating competitiveness and re-mating [48]. Monitoring and evaluating after sterile male insect release in the target area can be observed by following parameters: survival, mobility, dispersal characteristics, the spatial occupation of the habitat and the density of the target insect [40]. recently year, the use radioisotopes (gamma-rays) in male mosquito sterilization process of the SIT still being developed. BELLINI et al. [52,53] reported mating competitiveness of Aedes albopictus in Rimini, Italy, after gammairradiation on variety dose. The study states that mating competitiveness of Aedes albopictus decreasing on 30 to 60 Gy gamma-irradiation. OLIVA et al. [54] reported effects of irradiation, the presence of females and sugar supply on the longevity of Aedes albopictus in Reunion Island, France. Sterilization process using gamma-rays (137Cs), irradiation dose was 35 Gy. Results of

Table 2. Comparison of properties of Co-60 and Cs-137 [43]

\begin{tabular}{lll}
\hline \multirow{2}{*}{ Properties } & \multicolumn{2}{c}{ Radioisotopes } \\
\cline { 2 - 3 } & \multicolumn{1}{c}{ Co-60 } & \multicolumn{1}{c}{ Cs-137 } \\
\hline Production mode & Neutron absorption in nuclear & Chemical separation from spent \\
& reaction & nuclear fuel, e.g. uranium \\
Half-life (years) & 5,27 & 30,07 \\
Photon energy (MeV) & 1,17 and 1,33 & 0,66 \\
$50 \%$ dose decrease (depth in water) & $23 \mathrm{~cm}$ & $21 \mathrm{~cm}$ \\
\hline
\end{tabular}

The idea of the SIT using ionizing energy on insect pest control population had been conceived and pioneered by E. F. Knipling and R. Bushland of The United State Department of Agriculture (USDA) in the 1930s and 1940s [37,38]. Highly successful of SIT application integrated AW-IPM occurred in the 1950s, the elimination program of new world screwworm Cochliomya homonivorax (Coquerel), a deadly parasite of livestock in United State [37,49]. Cochliomya homonivorax (Coquerel) eradication campaign using SIT have been conducted over 45 years in the USA, Mexico, Belize, Guatemala, Honduras, El Salvador, Nicaragua, Costa Rica, Panama, Libya and North Africa [50]. Other target insects of the SIT program include the Mediterranean fruit fly (Medfly) Ceratitis capitata Wiedemann, the pink bollworm Pectinophora gossypiella Saunders, codling moth Cydia pomonella L., Tsetse flies, onion maggot and other insects [38].

On mosquito program, several release trials were conducted in the 1960s and 1970s, with the largest scale were conducted in El Salvador and India. The mosquito target in El Salvador was malaria vector Anopheles albimanus, while in India was Culex quinquefasciatus [51]. Until this study state that the presence of females reduced sterile male longevity, whilst sugar supply could counteract this effect. HASSAN et al. [55] reported swarming and mating behavior of malaria vector Anopheles arabiensis Patton, the SIT project in Sudan. The sterile male was observed to join natural swarm regularly, indicates that they have competitiveness with other normal (wild) male.

\section{Implementation of SIT in Indonesia}

In Indonesia, the regulatory control of nuclear energy as mandated by applicable laws and regulations were carried out by Nuclear Energy Regulatory Agency (BAPETEN, http://www.bapeten.go.id/?page_id=1130\&lang=e n). While, the institution which has the authority to manage nuclear energy and radioactive materials for research activities are National Nuclear Energy Agency (BATAN, http://www.batan.go.id/index.php/en/homeen/mission-vision). This institution has facilities involves research nuclear reactor, radioisotopes production, irradiator and installation of nuclear waste management. Radiation technique on agriculture research and development in Indonesia was applied to plant mutation breeding, insect pest 
control, plant nutrition and animal health. Implementation of SIT to control insect pest population in Indonesia has been conducted for 10 years ago. Main insect pests target are Bactrocera carambolae fruit fly, Aedes aegypti mosquito as dengue hemorrhagic fever (DHF) vector, Anopheles mosquito as malaria vector and Culex quinquefasciatus as filariasis vector. NASUTION and KUSWADI [58] reported Bactrocera carambolae mass rearing optimizing by dipping their eggs, use of low temperature and aeration. KUSWADI et al. [59] reported gamma-rays irradiation (0-50 Gy) on eggs and larval stage of Bactrocera carambolae to produce irradiation host for their parasitoid. The study states that both of object irradiated, there are no emerged as the adult, however it needs to be proved. NURHAYATI and RAHAYU [60] reported the SIT on Aedes aegypti population control. Gammarays in variety dose $(0 ; 65 ; 70 ; 75 ; 80$ and $85 \mathrm{~Gy})$ were administrated to Aedes aegypti on pupa stage. The optimal dose of sterilization process using gamma-ray irradiation was $70 \mathrm{~Gy}$, with $100 \%$ sterility level. SASMITA and ERNAWAN [56] reported the effects of gamma-rays irradiation which administrated to Aedes aegypti on pupa and adult stage. Then observed their quality parameter includes longevity, sterility level and mating competitiveness. The result showed that there were no significantly different of all parameter observation between pupa and adult stage gammarays administration. On Anopheles mosquito as malaria vector, NURHAYATI et al. [61] reported their study on sterilization process of Anopheles macullatus using gamma-rays irradiation (source: Co-60) in variety dose. The study can be summarized that optimal dose on sterilization process of Anopheles macullatus was $110 \mathrm{~Gy}$. On filariasis vector mosquito, SETIYANINGSIH et al. [57] reported effects of gamma-rays irradiation on sterility and embryo development of Culex quinquefasciatus. The optimal dose of sterilization process of this mosquito was $70 \mathrm{~Gy}$, with $100 \%$ sterility level.

\section{CONCLUDING REMARK AND FUTURE CHALLENGES}

Filariasis control program in Indonesia has a complicated challenge and requires deeps study. We faced the fact that the filariasis clinical cases in Indonesia caused by filarial parasites Brugia malayi, Brugia timori and Wuchereria bancrofti, where filarial parasites spread by mosquito vectors are specific in certain areas. To support the filariasis elimination program, it is necessary to update the mapping of filariasis in the entire territory of Indonesia with the main components include: the geographical conditions of the region, mosquitoes as vectors and filarial parasite species. The information necessary to study the filariasis cases in various regions in Indonesia on habitat and behavior of vector and parasite perspective. One of the main strategies, in order to support the global elimination program in 2020, especially in Indonesia, is by controlling the filariasis vector population and interrupting the interaction between human and vector.

SIT is a potential method that can be applied for filariasis elimination in Indonesia. SIT is a highly environment-friendly method of biological pest control that relies on mass rearing, gamma-rays sterilization and release a large number of sterile male insect, there is no pollutant produced. SIT also is a specific insect target and has no effect on other "non-target" species. By SIT application on filariasis elimination will not disturbing environment and non-target species habitat.

Technical challenges of SIT implementation in Indonesia begins from determining mass rearing method of target species in the laboratory (filariasis vector; i.e. Anopheles, Mansonia and Culex mosquitoes). Each target species has a specific and different method how to handling compared another [41]. We should find which more effective, efficient and applicable method on species target mass rearing. The dosage of gamma-rays sterilization process depends on species target. Thus, we have to determine the optimal sterilization dose. The parameter of quality control on SIT should be maintained during transportation and releasing of sterile male mosquito into filariasis endemic area.

Consider increasing effectiveness and successful of filariasis elimination program in Indonesia, SIT combined with other methods on AW-IPM. On AW-IPM, several methods applied together under one management include defining the geographic target area, extensive biological and ecological data to get the information of species target population dynamics, species traps and chemical control methods before SIT initiating [40]. Enthusiast of all stakeholders, especially public participation and contribution are 
needed to achieve successful filariasis elimination program goals.

\section{ACKNOWLEDGEMENT}

Authors would like to thank Fabrizio Balestrino, Ph.D for the valuable comments related the SIT concepts.

\section{REFERENCES}

1. Slatko B.E., Luck A.N., Dobson S.L., and Foster J.M., Wolbachia endosymbionts and human disease control, Mol. Biochem. Parasitol., vol. 195, no. 2, pp. 88-95, 2014.

2. Mcnulty S.N., Mitreva M., Weil G.J., and Fischer P.U., Inter and intra-specific diversity of parasites that cause lymphatic filariasis, Infect. Genet. Evol., vol. 14, no. 1, pp. 137-146, 2013.

3. Schaberle T.F., Schiefer A., Schmitz A., Konig G.M., Hoerauf A., and Pfarr K., Corallopyronin A-A promising antibiotic for treatment of filariasis, Int. J. Med. Microbiol., vol. 304, no. 1, pp. 72-78, 2014.

4. Michael E. and Bundy D.A.P., Global mapping of lymphatic filariasis, Parasitol. today, vol. 13, no. 12, pp. 472-476, 1997.

5. Cobo F., Imported infectious diseases: The impact in developed countries. Elsevier, 2014.

6. Mwakitalu M.E., Malecela M.N., Pedersen E.M., Mosha F.W., and Simonsen P.E., Urban lymphatic filariasis in the city of Tanga, Tanzania, after seven rounds of mass drug administration, Acta Trop., vo. 128, no. 3, pp. 692-700, 2013.

7. Aguiar-Santos A.M., Medeiros Z., Bonfim C., Rocha A.C., Brandao E., Miranda T., Oliveira P., and Sarinho E.S.C., Epidemiological assessment of neglected diseases in children: Lymphatic filariasis and soil-transmitted helminthiasis, $J$. Pediatr. (Rio. J)., vol. 89, no. 3, pp. 250-255, 2013.

8. Malik A., Singh V., Dahiya S.K., and Dutta V., Coexistence of filariasis with carcinoma breast-An incidental cytological finding, Med. J. Armed Forces India, vol. 71, pp. 76-78, 2015.

9. Sangwan S. and Singh S.P., Filariasis of the breast, Med. J. Armed Forces India, vol. 71, (Suppl 1), pp. 240-241, 2014.

10. Ruiz L., Campo E., and Corachan M., Elephantiasis in Sao Tome and Principe, Acta Trop., vol. 57, no. 1, pp. 29-34, 1994.

11. Ottesen E.A., Duke B.O., Karam M., and Behbehani K., Strategies and tools for the control/elimination of lymphatic filariasis., Bull. World Health Organ., vol. 75, no. 6, pp. 491, 1997.

12. King J.D., Zielinski-Gutierrez E., Pa'au M., and Lammie P., Improving community participation to eliminate lymphatic filariasis in American Samoa, Acta Trop., vol. 120, (SUPPL. 1), pp. 48-54, 2011.

13. Ramaiah K.D., Das P.K., and Dhanda V., Estimation of permissible levels of transmission of bancroftian filariasis based on some entomological and parasitological results of a 5 -year vector control programme, Acta Trop., vol. 56, no. 1, pp. 89-96, 1994.

14. Joe L.K., Rees D.M., Filariasis in Indonesia: distribution, incidence and vectors., Proceeding of Int. Cogress on Tropical Medicine and Malaria (6th), Lisbon, vol. 2, pp. 361-370, 1959.

15. Supali T., Wibowo H., Ruckert P., Fischer K., Ismid I.S., Djuardi Y., Fischer P., and Purnomo, High prevalence of Brugia timori infection in the highland of Alor Island, Indonesia., Am. J. Trop. Med. Hyg., vol. 66, no. 5, pp. 560-565, 2002. 
16. Supali T., Rahmah N., Djuardi Y., Sartono E., Ruckert P., and Fischer P., Detection of filaria-specific IgG4 antibodies using Brugia Rapid test in individuals from an area highly endemic for Brugia timori, Acta Trop., vol. 90, no. 3, pp. 255-261, 2004.

17. Partono F., Maizels R.M. and Purnomo, Towards a filariasis -free community: evaluation of filariasis control over an eleven year period in Flores, Indonesia, Trans. of the Royal Soc. Trop. Med. Hyg., vol. 83, no. 6, pp. 821-826, 1989.

18. Terhell A.J., Houwing-Duistermaat J.J., Ruiterman Y., Haarbrink M., Abadi K., and Yazdanbakhsh M., Clustering of Brugia malayi infection in a community in South-Sulawesi, Indonesia, Parasitology, vol. 120, no. 1, pp. 23-29, 2000.

19. Partono F. and Purnomo, Periodicity studies of Brugia malayi in Indonesia: recent findings and a modified classification of the parasite, Trans. R. Soc. Trop. Med. Hyg., vol. 81, no. 4, pp. 657-662, 1987.

20. Sasa M., Human filariasis. A global survey of epidemiology and control. University Park Press., 1976.

21. Bockarie M.J., Pedersen E.M., White G.B., and Michael E., Role of vector control in the global program to eliminate lymphatic filariasis, Annu. Rev. Entomol., vol. 54, pp. 469-487, 2009.

22. Suzuki T., Sudomo M., Bang Y.H., and Lim B.L., Studies on Malayan filariasis in Bengkulu (Sumatera), Indonesia with special reference to vector confirmation., Southeast Asian J. Trop. Med. Public Health, vol. 12, no. 1, pp. 47, 1981.

23. Sudomo M., Hanifah A., Mak J.W., and Lim B.L., A study of malayan filariasis in Lubuk Mumpo and Datar Lebar villages in Lais Regency, North Bengkulu, Sumatera, Indonesia., Southeast Asian J. Trop. Med. Public Health, vol. 13, no. 4, pp. 584-589, 1982.
24. Palmieri J.R., Masbar S., Purnomo, Marwoto H.A., Tirtoksumo S., and Darwis F., The domestic cat as a host for Brugian filariasis in South Kalimantan (Borneo), Indonesia, J. Helminthol., vol. 59, no. 3, pp. 277-281, 1985.

25. Yazdanbakhsh M., Paxton W.A., Kruize Y.C.M., Sartono E., Kurniawan A., Selkirk M.E., Partono F., Maizels R.M., and Van Het A.W., $\mathrm{T}$ cell responsiveness correlates differentially with antibody isotype levels in clinical and asymptomatic filariasis, J. Infect. Dis., vol. 167, no. 4, pp. 925-931, 1993.

26. Partono F., Oemijati S., Joesoef A., Sajidiman H., Putrali J., Clarke M.D., Carney W.P. and Cross J.H., Malayan filariasis in Central Sulawesi (Celebes), Indonesia., Southeast Asian J. Trop. Med. Public Health, vol. 8, no. 4, pp. 452-458, 1977.

27. Lien J.C., Kosman L., Partono F., Joesoef A., Kosin E., and Cross J.H., A Brief Survey of Mosquitoes in North Sumatra, Indonesia, J. Med. Entomol., vol. 12, no. 2, pp. 233-239, 1975.

28. Partono F., Pribadi P.W., and Soewarta A., Epidemiological and clinical features of Brugia timori in a newly established village. Karakuak, West Flores, Indonesia., Am. J. Trop. Med. Hyg., vol. 27, no. 5, pp. 910-915, 1978.

29. Joesoef A. and Dennis D.T., Intestinal and blood parasites of man on Alor Island Southeast Indonesia., Southeast Asian J. Trop. Med. Public Health, vol. 11, no. 1, pp. 43-47, 1980.

30. Dennis D.T., Partono F., Atmosoedjono P.S., and Saroso J.S., Timor filariasis: epidemiologic and clinical features in a defined community., Am. J. Trop. Med. Hyg., vol. 25, no. 6, pp. 797-802, 1976.

31. Hoedojo, Partono F., Atmosoedjono S., Purnomo, and Teren T., A study on vectors of Bancroftian filariasis in West Flores, Indonesia, Southeast Asian J. 
Trop. Med. Public Health, vol. 11, no. 3, pp. 399-404, 1980.

32. Lee V.H., Atmosoedjono S., Dennis D.T., Suhaepi A., and Suwarta A., The anopheline (Diptera: Culicidae) vectors of malaria and bancroftian filariasis in Flores Island, Indonesia, J. Med. Entomol., vol. 20, no. 5, pp. 577-578, 1983.

33. Joe L.K., Amaliah S., and others, "Wuchereria bancrofti infection in Djakarta, Indonesia, a study of some factors influencing its transmission.," Indian J. Malariol., vol. 14, no. 4, pp. 339-352, 1960.

34. Simonsen P.E. and Mwakitalu M.E., Urban lymphatic filariasis, Parasitol. Res., vol. 112, no. 1, pp. 35-44, 2013.

35. Harbut C.L., Filariasis in West Irian, Indonesia: a survey of six villages., $A m$. J. Trop. Med. Hyg., vol. 32, no. 4, pp. 764-766, 1983.

36. Rusmartini T. and Yuliantina F., Prevalence study of re-emerging lymphatic filariasis in West Java, Indonesia., in Proceedings of the Third ASEAN Congress of Tropical Medicine and Parasitology (ACTMP3), Bangkok, Thailand, pp. 125-129, (2009).

37. Knipling E.F., Possibilities of insect population control through the use of sexually sterile males, J. Econ Entomol, 48, (1955).

38 Klassen W. and Curtis C.F., History of the sterile insect technique, in Sterile Insect Technique, Springer, 3-36 (2005).

39. Klassen W., Area-wide integrated pest management and the sterile insect technique, in Sterile Insect Technique, Springer, 39-68 (2005).

40. Vreysen M.J.B., Robinson A.S., Hendrichs J., and Kenmore P., Area-wide integrated pest management (AW-IPM): principles, practice and prospects, in Area-wide control of insect pests, Springer, 3-33 (2007).

41. Parker A.G., Mass-rearing for sterile insect release, in Sterile Insect Technique, Springer, 209-232 (2005).

42. Robinson A.S., Genetic basis of the sterile insect technique, in Sterile Insect Technique, Springer, 95-114, (2005).

43. Bakri A., Mehta K., and Lance D.R., Sterilizing insects with ionizing radiation, in Sterile Insect Technique, Springer, 233-268, (2005).

44. Dongre T.K., Harwalkar M.R., Nene S.P. and Padwal-Desai S.R., Radio-sensitivity of different developmental stages of pulse beetle (Callosobruchus maculatus)., $J$. Food Sci. Technol., vol. 34, no. 5, pp. 413-415, 1997.

45. Lachance L.E. and Graham C.K., Insect radiosensitivity: Dose curves and dosefractionation studies of dominant lethal mutations in the mature sperm of 4 insect species, Mut. Res./Fundamental Mol. Mechanisms Mutagen. vol. 127, no. 1, pp. 49-59, 1984.

46. Fisher K., Irradiation effects in air and in nitrogen on Mediterranean fruit fly (Diptera: Tephritidae) pupae in Western Australia, J. Econ. Entomol., vol. 90, no. 6, pp. 1609-1614, 1997.

47. Dowell R.V.L, Worley J., and Gomes P.J., Sterile insect supply, emergence, and release, in Sterile Insect Technique, Springer, 297-324, (2005).

48. Calkins C.O. and Parker A.G., Sterile insect quality, in Sterile Insect Technique, Springer, 269-296, (2005).

49. Knipling E.F., Sterile-Male Method of Population Control: Successful with some insects, the method may also be effective when applied to other noxious animals, Science, vol. 130, (3380), pp. 902-904, 1959. 
50. Vargas-Teran M., Hofmann H.C., and Tweddle N.E., Impact of screwworm eradication programmes using the sterile insect technique, in Sterile Insect Technique, Springer, 629-650, 2005.

51. Benedict M.Q. and Robinson A.S., The first releases of transgenic mosquitoes: an argument for the sterile insect technique, Trends Parasitol., vol. 19, no. 8, pp. 349-355, 2003.

52. Bellini R., Calvitti M., Medici A., Carrieri M., Celli G., and Maini S., Use of the sterile insect technique against Aedes albopictus in Italy: First results of a pilot trial, in Area-wide control of insect pests, Springer, 505-515, 2007.

53. Bellini R., Balestrino F., Mediici A., Gentile G., Veronesi R., and Carrieri M., Mating competitiveness of Aedes albopictus radio-sterilized males in large enclosures exposed to natural conditions, J. Med. Entomol., vol. 50, no. 1, pp. 94-102, 2013.

54. Oliva C.F., Maier M.J., Gilles J., Jacquet M., Lemperiere G., Quilici S., Vreysen M.J.B., Schooneman F., Chadee D.D., and Boyer S., Effects of irradiation, presence of females, and sugar supply on the longevity of sterile males Aedes albopictus (Skuse) under semi-field conditions on Reunion Island, Acta Trop., vol. 125, no. 3, pp. 287-293, 2013.

55. Lees R.S., Knols B., Bellini R., Benedict M.Q., Bheecarry A., Bossin H.C., Chadee D.D., Charlwood J., Dabire R.K., Djogbenou L., Egyir-Yawson A., Gato R., Gouagna L.C., Hassan M.M., Khan S.A., Koekemoer L.L., Lemperiere G., Manoukis N.C., Mozuraitis R., Pitts R.J., Simard F., and Gilles J.R.L., Review: Improving our knowledge of male mosquito biology in relation to genetic control programmes, Acta Trop., vol. 132, no. 1, pp. 2-11, 2014.
56. Sasmita H.I. and Ernawan B., Kualitas Nyamuk Jantan Mandul Aedes aegypti L. Hasil Iradiasi Gamma: Efek Iradiasi Pada Fase Pupa dan Dewasa, J. Apl. Isot. Radiasi, vol. 10, no. 2, pp. 149-158, 2015.

57. Setiyaningsih R., Widiarti W., and Heriyanto B., Pengaruh Radiasi Sinar Gamma Co60 Terhadap Sterilitas Dan Perkembangan Embrio Culex Quinquefasciatus, Media Penelit. dan Pengemb. Kesehat., vol. 25, no. 1, pp. 51-58, 2015.

58. Nasution I.A. and Kuswadi A.N., Dipping of eggs, use of low temperature and aeration to improve fruit fly Bactrocera carambolae (Drew and Hancock) mass rearing in sterile insect technique programme. Proceedings of the Scientific Meeting on Research and Development of Isotopes Application and Radiation. Indonesia, 2004.

59. Kuswadi A.N., Indarwatmi M. and Nasution I.A., Irradiasi telur dan larva lalat buah Bactrocera carambolae (Drew and Hancock) untuk menghasilkan inang radiasi bagi parasitoidnya. Risalah seminar ilmiah penelitian dan pengembangan aplikasi isotop dan radiasi. Puslibang Teknologi Isotop dan Radiasi. Jakarta-Indonesia, 2004.

60. Nurhayati S. and Rahayu A., Potensi teknik nuklir dalam pengendalian nyamuk Aedes aegypti sebagai vector penyakit demam berdarah dengue (DBD). Prosiding pertemuan dan presentasi ilmiah-penelitian dasar ilmu pengetahuan dan teknologi nuklir, Yogyakarta, 2006.

61. Nurhayati S., Tetriana D., Rahayu A., and Santoso B., Pemandulan Anopheles macullatus sebagai vector penyakit malaria dengan radiasi gamma Co-60. Prosiding Seminar Nasional Keselamatan, Kesehatan dan Lingkungan IV dan Internasional Seminar on Occupational Health and Safety I, Jakarta, 2008. 
http://www.who.int/neglected_diseases/diseases/e n/ [accessed 2 December 2015].

http://www.depkes.go.id/article/view/1507300000 1/prevalansi-penyakit-kaki-gajahfilariasis-berhasil-diturunkan.html [accessed 2 December 2015].

http://www-naweb.iaea.org/na/ $\quad$ [accessed December 2015].

http://www-naweb.iaea.org/nafa/ipc/sterile-insecttechnique.html [accessed 2 December 2015].
Ministry of Health-Republic of Indonesia, 2015. Indonesia's Health Profile. Ministry Of Health.

http://www.depkes.go.id/resources/down load/pusdatin/profil-kesehatanindonesia/profil-kesehatan-indonesia2014.pdf [accessed 7 December 2015].

2 http://www.bapeten.go.id/?page_id=1130\&lang=e n [accessed 4 January 2016].

http://www.batan.go.id/index.php/en/homeen/mission-vision [accessed 5 January 2016]. 
Jurnal Ilmiah Aplikasi Isotop dan Radiasi

A Scientific Journal for The Applications of Isotopes and Radiation

p ISSN 1907-0322

Vol. 13 No. 1 Juni 2017

e ISSN 2527-6433 